\title{
Performance Of Mentik Wangi Rice Generation M1 From The Results Of Gamma Ray Irradiation
}

\author{
Ahmad Yunus 1), Sri Hartati1), Raden Dirgori Kuneng Brojokusumojo²)
}

\begin{abstract}
Mentik wangi is one of the local rice varieties in Indonesia less attractive to farmers. That is because the rice Mentik wangi has some weakness, namely a long harvest time, easy to collapse, and the results less than the maximum productivity. To increase the interest of farmers in rice cultivation Mentik wangi, then an attempt is made to improve the quality of rice Mentik wangi properties with plant breeding techniques one of which is a genetic mutation using gamma radiation. This study was conducted to determine the performance (performance) of rice Mentik wangi (M1) results of gammaray radiation that is expected to have a positive properties of new or better than its origin. This research was conducted in paddy fields in the village of Nangsri Lor, District Kebakkramat, Karanganyar and implemented in September 2015 to January 2016. Data were analyzed by descriptive with sorting and comparing each individual plant at each radiation dose to the average control accurately and objective. The results showed that gained some plants that could potentially be a mutant plant that has better properties (positive) that appears at the variable plants from each individual plant, ie the number of lines T16 with a radiation dose of 300 gray tall plants are very short $86 \mathrm{~cm}$, strain number T204 with a radiation dose of 200 gray pick the highest panicle length of 33.5 $\mathrm{cm}$, strain number T133 with a radiation dose of 100 gray has a total number of tillers and productive tiller high of 17 rods (total) and 11 rods (productive), strain number T133 with radiation dose of 200 gray had the highest number of filled grain and 624 grain strain T70 numbers with a radiation dose of 100 gray had the highest percentage of filled grain at $96 \%$, and the number of lines $T(1-7)$ with a radiation dose of 100 gray and strain number $T(1-9)$ with a radiation dose of 200 gray had a shorter harvesting time is 110 days.
\end{abstract}

Keywords : performance, gamma radiation, mutant plant

\section{PENDAHULUAN}

Mentik wangi merupakan varietas lokal tanaman Padi (Oryza Sativa L.) di Indonesia. Mentik wangi berasal dari kabupaten Magelang, Jawa Tengah. Padi varietas Mentik wangi mempunyai keunggulan yaitu pada aromanya yang khas dan alami serta tekstur beras yang pulen sehingga diminati sebagian besar masyarakat Indonesia untuk dikonsumsi. Namun, varietas Mentik wangi mempunyai kelemahan yaitu pada umur panen sekitar 125 hari (4 bulan) sehingga kurang diminati oleh petani untuk ditanam karena melebihi umur panen rata-rata sekitar 3 bulan. Selain itu, kelemahan Mentik wangi terdapat pada tingkat kerabahannya yaitu mudah roboh (Abdullah et al. 2006).

\footnotetext{
1)Lecturer Staff of Study Program of Agrotechnology, Faculty of Agriculture, Sebelas Maret University (UNS) on Surakarta.

2)Undergraduate Student of Study Program of Agrotechnology, Faculty of Agriculture, Sebelas Maret University (UNS) on Surakarta.

Contact Author: radendirgory_tkg@yahoo.co.id
}

Potensial yang dimiliki padi Mentik wangi tersebut dapat dipertahankan sedangkan kelemahan yang dimiliki padi Mentik wangi dapat dikembangkan untuk meningkatkan hasil produktivitasnya. Pengembangan pemuliaan tanaman telah banyak dilakukan salah satunya dengan teknik modern yaitu iradiasi sinar gamma. Sinar gamma adalah salah satu mutagen fisik yang sering digunakan dalam teknik mutagenesis tanaman.

Mutasi yang diharapkan adalah yang dapat menimbulkan keragaman pada sifat yang akan diseleksi sehingga sifat atau karakter yang lebih baik dapat diseleksi, sementara karakter yang baik pada tanaman/varietas asal tetap dipertahankan. Tujuan dari penelitian ini adalah untuk untuk mendapatkan informasi keragaan padi Mentik wangi (M1) hasil radiasi sinar gamma, serta menyeleksi individu-individu tanaman hasil radiasi yang menghasilkan karakter lebih baik dibandingkan induknya.

Percobaan penelitian mengenai induksi mutasi iradiasi sinar gamma telah banyak dilakukan di Indonesia khusunya oleh Badan Tenaga Nuklir Nasional (BATAN). Sampai saat ini, kegiatan pemuliaan mutasi di BATAN telah menghasilkan 22 varietas unggul tanaman yang terdiri atas 15 padi, 5 kedelai, 1 kacang hijau, 
dan 1 kapas (BB-BIOGEN 2011). Salah satu varietas padi yang telah berhasil dihasilkan dan memunyai keunggulan positif yaitu pada varietas sidenuk yang berasal dari iradiasi sinar gamma pada varietas pandan wangi.

Dosis iradiasi yang digunakan untuk menginduksi keragaman sangat menentukan keberhasilan terbentuknya tanaman mutan. Jika iradiasi dilakukan pada benih (seperti padi), pada umumnya kisaran dosis yang efektif lebih tinggi yaitu antara 100-500 Gray dibandingkan jika dilakukan pada bagian tanaman lainnya seperti tanaman hias (anyelir dan krisan) yang hanya pada dosis iradiasi antara 25-120 Gray). Hal ini dikarenakan setiap jenis, bagian, dan umur tanaman memiliki sensitivitas dan tanggap yang berbeda terhadap jenis dan dosis iradiasi. Dosis mutagen yang tinggi akan menyebabkan frekuensi terjadinya mutasi menjadi semakin tinggi. Dosis yang dianggap efektif adalah dosis yang mengakibatkan kematian $50 \%$ (LD50) dari populasi yang mendapat perlakuan (Ramchander et al. 2014). Menurut Taher et al. (2011) bahwa penentuan dosis iradiasi yang efektif merupakan prasyarat untuk pembibitan dan pengembangan variasi genetik hasil mutasi. Pada tanaman padi, dosis yang disarankan adalah lebih rendah dari kurva LD $_{50}$ (Lethal Dose 50) yaitu di bawah dosis 500 Gray (Khikmah 2014). LD 50 adalah dosis yang menyebabkan $50 \%$ kematian dari populasi yang diradiasi (Ritonga dan Wulansari 2011).

\section{METODE PENELITIAN}

Penelitian dilaksanakan pada bulan September 2015 sampai Januari 2016. Penelitian dilakukan pada lahan sawah di Desa Nangsri Lor, Kecamatan Kebakkramat, Kabupaten Karanganyar dengan ketinggian tempat $95 \mathrm{mdpl}$ dan termasuk jenis tanah sawah berordo Inceptisol atau Alluvial. Radiasi benih padi Mentik Wangi dengan sinar gamma dilaksanakan di Pusat Aplikasi Isotop dan Radiasi (PAIR), Badan
Tenaga Atom Nasional (BATAN) Jakarta Selatan. Alat yang digunakan pada penelitian ini diantaranya alat untuk meradiasi benih "Gamma Chamber Cobalt 60", patok, alat tulis, meteran, papan label, jaring, toples, koran atau kertas folio (dibentuk amplop), seperangkat alat untuk analisis laboratorium dan di lapang. Bahan yang digunakan diantaranya benih padi Mentik wangi, pupuk kandang sapi, urea, SP36 dan $\mathrm{KCl}$.

Penelitian menggunakan rancangan perlakukan pengamatan pada setiap individu masing-masing dosis radiasi dengan membandingkan nilai rata-rata perlakuan kontrol untuk mengetahui perbedaan dan pengaruh radiasi terhadap pertumbuhan padi Mentik wangi. Perlakuan penelitian ini terdiri dari 773 benih padi Mentik wangi dengan diberikan 3 dosis radiasi sinar gamma. Tanpa perlakuan Radiasi atau kontrol (R0) berjumlah 100 benih, dosis 100 gray (R1) berjumlah 232 benih, dosis 200 gray (R2) berjumlah 221 benih, dan dosis 300 gray (R3) berjumlah 221 benih. Data yang diperoleh dianalisis secara deskriptif dengan membandingkan setiap individu tanaman pada masing-masing dosis radiasi dengan rata-rata kontrol karena penelitian ini memiliki tujuan untuk mengetahui simpangan positif perkembangan kualitas dari suatu individu secara akurat dan objektif.

\section{HASIL DAN PEMBAHASAN}

\section{Tinggi Tanaman}

Tinggi tanaman padi yang baik secara umum ialah mempunyai tinggi tanaman yang pendek $(<115 \mathrm{~cm})$. Berdasarkan Tabel 1, tinggi tanaman terendah dan merupakan kelompok tinggi tanaman terbaik berada pada galur T16 dosis radiasi 300 gray yaitu $86 \mathrm{~cm}$. Nilai kisaran masing-masing perlakuan 100, 200, dan 300 gray lebih luas dibandingkan perlakuan tanpa radiasi menunjukkan keragaman genetiknya lebih luas.

Tabel 1. Tinggi Tanaman Pada Berbagai Dosis Radiasi

\begin{tabular}{|c|c|c|c|c|c|c|}
\hline \multirow{2}{*}{$\begin{array}{l}\text { Dosis } \\
\text { radiasi } \\
\text { (gray) }\end{array}$} & \multicolumn{2}{|c|}{ Tinggi tanaman terendah } & \multicolumn{2}{|c|}{ Tinggi tanaman tertinggi } & \multirow{2}{*}{$\begin{array}{l}\text { Kisaran } \\
\text { (cm) }\end{array}$} & \multirow{2}{*}{$\begin{array}{l}\text { Rata } \\
\text {-rata } \\
\text { (cm) }\end{array}$} \\
\hline & Galur & Tinggi tanaman (cm) & Galur & Tinggi tanaman $(\mathrm{cm})$ & & \\
\hline 0 & T43 & 107 & T6 & 134 & $107-134$ & 116 \\
\hline 100 & T210 & 102 & T29 & 143 & $102-143$ & 123 \\
\hline 200 & T215 & 101 & T43 & 144 & $101-144$ & 124 \\
\hline 300 & $\mathrm{~T} 16$ & 86 & T35 & 147 & $86-147$ & 117 \\
\hline
\end{tabular}

Tinggi tanaman yang lebih pendek menjadikan tanaman tahan rebah karena angin dan sebagainya. Sobrizal (2006) dalam penelitiannya bahwa semakin pendek tanaman diharapkan tanaman tersebut tidak mudah roboh karena terpaan angin. Indikasi terjadinya mutasi 7 yaitu terdapatnya perubahan kenampakkan fenotipe yang nampak terlihat tinggi tanaman lebih kerdil. Pemuliaan tanaman dengan perlakuan iradiasi pada varietas padi Ase lapang dan Mandoti dapat menyebabkan beberapa perubahan karakter morfologi seperti tinggi Agrosains 19(1): 6-14, 2017 
tanaman lebih pendek dari yang tidak di radiasi (Haris et al. 2013). Indikasi terjadinya mutasi lainnya yaitu pada keragaman yang lebih luas yang ditunjukkan dari nilai kisaran pada perlakuan dosis radiasi memiliki nilai kisaran lebih luas dibandingkan dengan perlakuan kontrol. Semakin tingginya dosis radiasi yang diberikan mengakibatkan semakin tingginya selisih kisaran tinggi tanaman, semakin tingginya variasi nilai kisaran maka semakin luasnya besar keragaman dan semakin luasnya keragaman genetik. Hal tersebut sesuai dengan pernyataan Kumar et al. (2013), bahwa hasil penelitian yang pernah dilakukan menunjukkan penurunan tinggi tanaman padi degan meningkatkan dosis iradiasi, dan penurunan dosis iradiasi tersebut berbanding lurus dengan pengaruh peningkatan tinggi tanaman.

\section{Jumlah Anakan Total}

Jumlah anakan total berkorelasi positif dengan hasil produktivitas yang lebih baik. Indikasi terjadinya mutasi dilakukan dengan menyeleksi dan memilah individu jumlah anakan total terbaik yaitu dengan membandingkan individu jumlah anakan total terbanyak yang terdapat pada galur T133 dosis radiasi 100 gray berjumlah anakan total 17 batang dengan ratarata perlakuan tanpa radiasi memiliki jumlah anakan total 6 batang. Indikasi terjadinya mutasi dapat dilihat dari nilai kisaran bahwa nilai perlakuan pemberian dosis radiasi menunjukkan keragaman genetik lebih luas berkisar antara (317, 3-12, 3-11 batang) dibandingkan dengan nilai kisaran perlakuan tanpa radiasi yang memiliki keragaman genetik lebih sempit berkisar 3-9 batang.

Tabel 2. Jumlah Anakan Total Pada Berbagai Dosis Radiasi

\begin{tabular}{|c|c|c|c|c|c|c|}
\hline \multirow{2}{*}{$\begin{array}{c}\text { Dosis } \\
\text { radiasi } \\
\text { (gray) }\end{array}$} & \multicolumn{2}{|c|}{ Anakan total terendah } & \multicolumn{2}{|c|}{ Anakan total terbanyak } & \multirow[b]{2}{*}{$\begin{array}{r}\text { Kisaran } \\
\text { (batang) }\end{array}$} & \multirow[b]{2}{*}{$\begin{array}{l}\text { Rata-rata } \\
\text { (batang) }\end{array}$} \\
\hline & Galur & $\begin{array}{c}\text { Jumlah } \\
\text { (batang) }\end{array}$ & Galur & $\begin{array}{c}\text { Jumlah } \\
\text { (batang) }\end{array}$ & & \\
\hline 0 & T67 & 3 & T46 & 9 & $3-9$ & 6 \\
\hline 100 & $\begin{array}{c}\text { T7, T37, T216, } \\
\text { T226 }\end{array}$ & 3 & $\mathrm{~T} 133$ & 17 & $3-17$ & 7 \\
\hline 200 & T1 & 3 & $\begin{array}{c}\text { T16, T115, } \\
\text { T204 }\end{array}$ & 12 & $3-12$ & 7 \\
\hline 300 & T69, T107, T109 & 3 & T97, T220 & 11 & $3-11$ & 6 \\
\hline
\end{tabular}

Mohamad et al. (2006) mengungkapkan banyak mutan yang telah diidentifikasi dan terbukti lebih baik dari tetua mereka dengan cara menyeleksi dan memilah hasil terbaik. Jumlah anakan total lebih banyak menunjukkan munculnya peluang individu yang mempunyai lebih baik dan diharapkan dapat meningkatkan hasil produktivitas. Kartikaningrum dan Effendie (2005) bahwa keragaman genetik yang luas merupakan syarat keberhasilan seleksi terhadap sifat yang diinginkan dalam proses pemuliaan tanaman dan keragaman yang lebih luas mengindikasi keberhasilan mutasi tanaman.

\section{Jumlah Anakan Produktif}

Jumlah anakan produktif terbaik memiliki jumlah anakan produktif lebih banyak yang terdapat pada galur T133 dengan dosis radiasi 100 gray yakni 11 batang dibandingkan dengan rata-rata kontrol memiliki rata-rata jumlah anakan produktif yaitu 5 batang. Indikasi terjadinya mutasi lainnya dapat dilihat dari nilai kisaran pada Tabel 3, bahwa nilai kisaran perlakuan pemberian dosis radiasi menunjukkan keragaman genetik lebih luas (3-11, 3-9, 2-8 batang) dibandingkan perlakuan kontrol (3-7 batang).

Tabel 3. Jumlah Anakan Produktif Pada Berbagai Dosis Radiasi

\begin{tabular}{|c|c|c|c|c|c|c|}
\hline \multirow{2}{*}{$\begin{array}{c}\text { Dosis } \\
\text { radiasi } \\
\text { (gray) }\end{array}$} & \multicolumn{2}{|c|}{ Anakan produktif terendah } & \multicolumn{2}{|c|}{ Anakan produktif terbanyak } & \multirow{2}{*}{$\begin{array}{l}\text { Kisaran } \\
\text { (batang) }\end{array}$} & \multirow[b]{2}{*}{$\begin{array}{c}\text { Rata-rata } \\
\text { (batang) }\end{array}$} \\
\hline & Galur & $\begin{array}{l}\text { Jumlah } \\
\text { (batang) }\end{array}$ & Galur & $\begin{array}{l}\text { Jumlah } \\
\text { (batang) }\end{array}$ & & \\
\hline 0 & \multirow{2}{*}{$\begin{array}{c}\text { T67, T68 } \\
\text { T75, T26, T30, } \\
\text { T57 }\end{array}$} & 3 & T36, T38, T51 & 7 & $3-7$ & 5 \\
\hline 100 & & 2 & $\mathrm{~T} 133$ & 11 & $2-11$ & 5 \\
\hline 200 & T29 & 2 & $\begin{array}{c}\text { T16, T39, T53, T102, } \\
\text { T116, T133 }\end{array}$ & 9 & $2-9$ & 6 \\
\hline 300 & $\mathrm{~T} 1, \mathrm{~T} 17$ & 2 & T62, T220 & 8 & $2-8$ & 5 \\
\hline $\begin{array}{l}\text { Juml } \\
\text { menunjuk } \\
\text { dengan } \\
\text { individu t }\end{array}$ & $\begin{array}{l}\text { anakan proc } \\
\text { n bahwa terjac } \\
\text { dapatnya peruk } \\
\text { dman. Hasil per }\end{array}$ & $\begin{array}{l}\text { f lebih } \\
\text { mutasi } \\
\text { n fenotip } \\
\text { an Wijay }\end{array}$ & $\begin{aligned} \text { anyak } & \text { bahwa p } \\
\text { itandai } & \text { menghasilk } \\
\text { pada } & \text { dibandingk } \\
\text { (2006) } & \text { menunjukk }\end{aligned}$ & $\begin{array}{l}\text { kuan dc } \\
\text { jumlah } \\
\text { control pa } \\
\text { terjadiny }\end{array}$ & $\begin{array}{l}\text { radias } \\
\text { lakan le } \\
\text { tanaman } \\
\text { erubahar }\end{array}$ & $\begin{array}{l}20 \text { gray } \\
\text { banyak } \\
\text { ledri yang } \\
\text { ifat yang }\end{array}$ \\
\hline
\end{tabular}


tampak. Menurut Herawati et al. (2009) bahwa keragaman genetik ditentukan dari luasnya perbedaan nilai suatu kisaran dalam populasi tanaman tersebut, dalam hasil penelitiannya pada persilangan tanaman padi Gogo dengan sifat-sifat tipe baru hasil kultur Antera menjelaskan terdapat kisaran anakan produktif tertinggi yang menunjukkan keragaman yang luas yaitu pada galur hasil kultur antera dari persilangan Fatmawati/Way Rarem, galur hasil kultur antera dari Fatmawati/SGJT-36, galur hasil kultur antera dari Way Rarem/Fatmawati, dan galur hasil kultur antera dari SGJT36/Fatmawati lebih tinggi dari tetua.

\section{Panjang Malai}

Tanaman mutan dengan sifat lebih baik yang muncul dapat diketahui dari panjang malai tertinggi pada masing-masing galur dibandingkan dengan rata-rata panjang malai tanpa radiasi. Berdasarkan Tabel 4, panjang malai tertinggi terdapat pada galur T204 dengan dosis radiasi 200 gray yaitu $33,5 \mathrm{~cm}$. Panjang malai tertinggi tersebut lebih baik dibandingkan dengan ratarata kontrol yakni $27,011 \mathrm{~cm}$. Kisaran panjang malai menunjukkan bahwa pemberian dosis radiasi sinar gamma memiliki keragaman yang lebih luas dibandingkan dengan perlakuan tanpa radiasi. Panjang malai tertinggi dapat mempengaruhi hasil produktivitas gabah padi karena panjang malai secara nyata berkorelasi positif dengan bobot gabah per rumpun, yang tidak lain adalah hasil produktivitas per ha (Bakhtiar et al. 2010).

Tabel 4. Panjang Malai Pada Berbagai Dosis Radiasi

\begin{tabular}{|c|c|c|c|c|c|c|}
\hline \multirow{2}{*}{$\begin{array}{c}\text { Dosis } \\
\text { radiasi } \\
\text { (gray) }\end{array}$} & \multicolumn{2}{|c|}{$\begin{array}{c}\text { Panjang malai } \\
\text { terpendek }\end{array}$} & \multicolumn{2}{|c|}{ Panjang malai terpanjang } & \multirow{2}{*}{$\begin{array}{l}\text { Kisaran } \\
\text { (cm) }\end{array}$} & \multirow{2}{*}{$\begin{array}{c}\text { Rata-rata } \\
\text { (cm) }\end{array}$} \\
\hline & Galur & $\begin{array}{l}\text { Panjang malai } \\
(\mathrm{cm})\end{array}$ & Galur & $\begin{array}{l}\text { Panjang malai } \\
(\mathrm{cm})\end{array}$ & & \\
\hline 0 & T19 & 21 & $\begin{array}{c}\text { T5, T15, T16, } \\
\text { T37 }\end{array}$ & 29,5 & $21-29,5$ & 27,011 \\
\hline $\begin{array}{l}100 \\
200\end{array}$ & $\begin{array}{l}\text { T26 } \\
\text { T94 }\end{array}$ & $\begin{array}{l}19 \\
21\end{array}$ & $\begin{array}{l}\text { T49 } \\
\text { T204 }\end{array}$ & $\begin{array}{l}31,5 \\
33,5\end{array}$ & $\begin{array}{l}19-31,5 \\
21-33,5\end{array}$ & $\begin{array}{l}26,09 \\
26,52\end{array}$ \\
\hline 300 & T124 & 19,5 & T64, T220 & 29,5 & $\begin{array}{c}19,5- \\
29,5\end{array}$ & 25,85 \\
\hline
\end{tabular}

Nilai kisaran perlakuan radiasi lebih luas dibandingkan perlakuan tanpa radiasi menandakan bahwa terjadinya mutasi pada masing-masing individu yang menimbulkan semakin besarnya peluang dalam mendapatkan tanaman mutan bersifat lebih baik dari induknya. Keberhasilan program pemuliaan tanaman sangat tergantung oleh tersedianya keragaman genetik, semakin luas keragaman genetik yang dimiliki akan semakin besar peluang keberhasilan bagi program pemuliaan tanaman (Martono 2010).

5. Jumlah Gabah Isi Per Rumpun dan Persentase Gabah Isi Per Rumpun

Indikasi terjadinya mutasi pada pengamatan peubah jumlah gabah isi terdapat pada kenampakkan fenotipe jumlah gabah isi terbanyak dan terendah yaitu jumlah gabah isi terbanyak berada pada galur T133 dengan dosis radiasi 200 gray sebanyak 624 biji dan jumlah gabah isi terendah berada pada galur T76 dengan dosis radiasi 300 gray sebanyak 15 biji dibandingkan dengan rata-rata jumlah gabah isi yaitu 281 biji. Hal tersebut menandakan terjadinya perubahan yang tampak pada galur terendah dan terbanyak dibandingkan sifat perlakuan tanpa radiasi.

Indikasi terjadinya mutasi lainnya dalam peubah jumlah gabah isi per rumpun ialah pada keragaman yang luas. Keragaman yang luas dapat diketahui pada nilai kisaran pada perlakuan dosis radiasi 100 , 200, dan 300 gray lebih tinggi atau luas dibandingkan dengan nilai kisaran perlakuan tanpa radiasi. 
Tabel 5. Jumlah Gabah Isi Per Rumpun Pada Berbagai Dosis Radiasi

\begin{tabular}{|c|c|c|c|c|c|c|c|c|}
\hline \multirow{2}{*}{$\begin{array}{l}\text { Dosis } \\
\text { radiasi } \\
\text { (gray) }\end{array}$} & \multicolumn{3}{|c|}{ Jumlah gabah isi terendah } & \multicolumn{3}{|c|}{ Jumlah gabah isi tertinggi } & \multirow{2}{*}{$\begin{array}{c}\text { Kisaran } \\
\text { (biji) }\end{array}$} & \multirow{2}{*}{$\begin{array}{c}\text { Rata-rata } \\
\text { (biji) }\end{array}$} \\
\hline & Galur & $\begin{array}{c}\text { Jumlah } \\
\text { (biji) }\end{array}$ & $\begin{array}{c}\text { Persentase } \\
(\%)\end{array}$ & Galur & $\begin{array}{c}\text { Jumlah } \\
\text { (biji) }\end{array}$ & $\begin{array}{c}\begin{array}{c}\text { Persentase } \\
(\%)\end{array} \\
\end{array}$ & & \\
\hline 0 & T68 & 158 & 61 & T60 & 450 & 75 & $158-450$ & 281 \\
\hline 100 & T26 & 32 & 75 & T232 & 469 & 62 & $32-462$ & 203,1 \\
\hline 200 & T73 & 33 & 14 & $\mathrm{~T} 133$ & 624 & 37 & $33-624$ & 226,2 \\
\hline 300 & T76 & 15 & 7 & $\mathrm{~T} 174$ & 432 & 83 & $15-432$ & 120,7 \\
\hline
\end{tabular}

Interaksi adanya perubahan sifat yang tampak akibat radiasi sinar gamma memberikan respons lebih baik yaitu berada pada genotipe padi Pare Lotong dengan dosis 300 Gray untuk parameter jumlah gabah berisi per malai $88,31 \%$ lebih baik dari perlakuan tanpa radiasi (Shaleh 2013). Perlakuan dosis radiasi 200 gray mempunyai selisih nilai kisaran tertinggi sehingga keragaman genetiknya lebih luas dibandingkan dengan perlakuan tanpa radiasi.
Berdasarkan Tabel 6, persentase gabah isi tertinggi berada pada galur T70 degan dosis radiasi 100 gray yaitu $96 \%$. Jumlah gabah isi tertinggi dan persentase tertinggi memiliki peluang besar menjadi tanaman mutan yang memiliki sifat lebih baik. Jumlah gabah isi dan persentase tinggi menunjukkan produktivitas hasil gabah tinggi. Nilai kisaran yang memiliki keragaman genetik lebih luas terdapat pada dosis radiasi 100 gray yaitu berkisar $12-92 \%$.

Tabel. 6. Persentase Gabah Isi Per Rumpun Pada Berbagai Dosis Radiasi

\begin{tabular}{|c|c|c|c|c|c|c|c|c|}
\hline \multirow{2}{*}{$\begin{array}{l}\text { Dosis } \\
\text { radiasi } \\
\text { (gray) }\end{array}$} & \multicolumn{3}{|c|}{ Persentase gabah isi terendah } & \multicolumn{3}{|c|}{ Persentase gabah isi tertinggi } & \multirow[b]{2}{*}{$\begin{array}{c}\text { Kisaran } \\
(\%)\end{array}$} & \multirow{2}{*}{$\begin{array}{c}\text { Rata } \\
\text {-rata } \\
(\%) \\
\end{array}$} \\
\hline & Galur & $\begin{array}{c}\text { Persentase } \\
(\%)\end{array}$ & $\begin{array}{c}\text { Jumlah } \\
\text { (biji) }\end{array}$ & Galur & $\begin{array}{c}\text { Persentase } \\
(\%)\end{array}$ & $\begin{array}{c}\text { Jumlah } \\
\text { (biji) }\end{array}$ & & \\
\hline 0 & T47 & 58 & 300 & T42 & 88 & 400 & $58-88$ & 74,3 \\
\hline 100 & T179 & 12 & 108 & T70 & 96 & 136 & $12-92$ & 62 \\
\hline 200 & T44 & 12 & 48 & T77 & 88 & 110 & $12-88$ & 56,9 \\
\hline 300 & T37 & 4 & 16 & T199 & 69 & 212 & $4-69$ & 34,5 \\
\hline
\end{tabular}

Keragaman yang luas merupakan salah satu syarat terhadap seleksi pada sifat yang diinginkan karena proses seleksi terhadap sifat tersebut akan lebih efisien. Sesuai dengan Vaughan et al. (2003) bahwa apabila keragaman genetik dalam suatu populasi besar, hal ini menunjukkan individu dalam populasi beragam sehingga peluang untuk memperoleh genotipe yang diharapkan lebih besar atau luas. Semakin luas keragaman genetik yang dimiliki akan semakin besar peluang keberhasilan program pemuliaan. Keragaman genetik yang sempit atau luas dapat mendistribusikan harapan habitat dan populasi yang dapat dipengaruhi oleh spesie dan lingkungan (Medrano dan Herrera 2008). Keragaman yang luas juga dapat meningkatkan tanggapan seleksi (selection response) karena tanggapan seleksi berbanding lurus dengan keragaman genetik (Kristamtini et al. 2014).
6. Jumlah Gabah Hampa Per Rumpun dan Persentase Gabah Hampa Per Rumpun Indikasi terjadinya mutasi pada pengamatan peubah jumlah gabah hampa per rumpun terdapat pada kenampakkan fenotipe jumlah gabah hampa terendah yaitu berada pada galur T7 dengan dosis radiasi 100 gray sebanyak 7 biji dibandingkan dengan rata-rata jumlah gabah hampa yaitu 99 biji. Indikasi terjadinya mutasi lainnya dalam pengamatan peubah jumlah gabah hampa per rumpun ialah pada keragaman yang luas. Keragaman yang luas dapat diketahui pada nilai kisaran pada perlakuan dosis radiasi 100, 200, dan 300 gray lebih tinggi atau luas dibandingkan dengan nilai kisaran perlakuan tanpa radiasi (kontrol). Kisaran lebih luas dan tertinggi berada pada pemberian dosis radiasi 200 gray yaitu 17-935 biji. 
Tabel 7. Jumlah Gabah Hampa Per Rumpun Pada Berbagai Dosis Radiasi

\begin{tabular}{ccccccccc}
\hline $\begin{array}{c}\text { Dosis } \\
\text { radiasi } \\
\text { (gray) }\end{array}$ & \multicolumn{2}{c}{ Jumlah gabah hampa terendah } & \multicolumn{2}{c}{ Jumlah gabah hampa tertinggi } & Kisaran & $\begin{array}{c}\text { Rata- } \\
\text { rata }\end{array}$ \\
\cline { 2 - 8 } & Galur & $\begin{array}{c}\text { Jumlah } \\
\text { (biji) }\end{array}$ & $\begin{array}{c}\text { Persentase } \\
\text { (\%) }\end{array}$ & Galur & $\begin{array}{c}\text { Jumlah } \\
\text { (biji) }\end{array}$ & $\begin{array}{c}\text { Persentase } \\
\text { (\%) }\end{array}$ & $\begin{array}{c}\text { (biji) } \\
\text { (biji) }\end{array}$ \\
\hline 0 & T80 & 33 & 17 & T45 & 219 & 34 & $33-219$ & 99,9 \\
100 & T7 & 7 & 4 & T18 & 898 & 83 & $7-898$ & 160,7 \\
200 & T157 & 12 & 17 & T119 & 935 & 85 & $17-935$ & 210,8 \\
300 & T35 & 21 & 37 & T85 & 879 & 83 & $37-879$ & 262,9 \\
\hline
\end{tabular}

Keberhasilan mutasi yang menandakan terjadinya perubahan yang tampak (fenotipe) menunjukkan bahwa sifat individu semakin beragam yang dapat dilihat pada nilai kisaran bahwa tingkatan dosis radiasi 200 gray memiliki keragaman genetik lebih luas dan memperbesar peluang kemuncullan berbagai sifat tanaman mutan.

Indikasi terjadinya mutasi pada pengamatan peubah persentase jumlah gabah hampa per rumpun terdapat pada kenampakkan fenotipe persentase jumlah gabah hampa terbanyak dan

Tabel 8. Persentase Gabah Hampa Per Rumpun Pada Berbagai Dosis Radiasi

\begin{tabular}{|c|c|c|c|c|c|c|c|c|}
\hline \multirow{2}{*}{$\begin{array}{c}\text { Dosis } \\
\text { radiasi } \\
\text { (gray) }\end{array}$} & \multicolumn{3}{|c|}{$\begin{array}{l}\text { Persentase gabah hampa } \\
\text { terendah }\end{array}$} & \multicolumn{3}{|c|}{$\begin{array}{c}\text { Persentase gabah hampa } \\
\text { tertinggi }\end{array}$} & \multirow{2}{*}{$\begin{array}{l}\text { Kisaran } \\
(\%)\end{array}$} & \multirow{2}{*}{$\begin{array}{c}\text { Rata } \\
\text {-rata } \\
\text { (\%) }\end{array}$} \\
\hline & Galur & $\begin{array}{l}\text { Persentase } \\
(\%)\end{array}$ & $\begin{array}{c}\text { Jumlah } \\
\text { (biji) }\end{array}$ & Galur & $\begin{array}{c}\text { Persentase } \\
(\%)\end{array}$ & $\begin{array}{c}\text { Jumlah } \\
\text { (biji) }\end{array}$ & & \\
\hline 0 & T42 & 12 & 55 & T47 & 42 & 217 & $12-42$ & 25,6 \\
\hline 100 & $\mathrm{~T} 173$ & 8 & 12 & T179 & 88 & 792 & $8-88$ & 37,9 \\
\hline 200 & T77 & 12 & 15 & T44 & 88 & 352 & $12-88$ & 43 \\
\hline 300 & T199 & 31 & 95 & T37 & 96 & 384 & $31-96$ & 65,4 \\
\hline
\end{tabular}

Hasil penelitian Herawati et al. (2009) menunjukkan nilai KKG pada persentase kehampaan padi gogo hasil kultur antera mencapai 35,79 \% lebih sempit keragaman genetiknya dibandingkan dengan nilai KKG pada persentase kehampaan padi gogo hasil kultur antera silangan Way rarem mencapai 36,35\% dan silangan Fatmawati 43,58 \% lebih luas keragaman genetiknya. Setara dengan Islam et al. (2016) bahwa karakter dengan KKG (Koefisien Keragaman Genotipe) rendah termasuk berkeragaman genetiksempit, sedangkan karakter dengan kriteria KKG cukup tinggi termasuk berkeragaman genetik lebih luas. terendah yaitu persentase jumlah gabah hampa terbanyak berada pada galur T37 dengan dosis radiasi 300 gray sebesar $96 \%$ dan persentase jumlah gabah hampa terendah berada pada galur T173 dengan dosis radiasi 100 gray sebesar $8 \%$ dibandingkan dengan rata-rata persentase jumlah gabah hampa yaitu $25,6 \%$. Hal tersebut menandakan terjadinya perubahan yang tampak (fenotipe) pada galur terendah dan terbanyak dibandingkan sifat perlakuan tanpa radiasi yang menandakan keberhasil mutasi.

\section{Umur Panen}

Umur panen yang lebih pendek menunjukkan adanya toleransi umur panen yang dipengaruhi oleh adanya mutasi. Indikasi terjadinya mutasi pada peubah umur panen dapat dilihat pada Gambar 1 ditandai dengan adanya perubahan sifat yang tampak yaitu pada beberapa galur tanaman menandakan umur panen lebih awal atau umur berbunga lebih cepat. Berdasarkan Tabel 9 menunjukkan bahwa rata-rata umur panen setiap peningkatan dosis radiasi menyebabkan keragaman yang lebih luas dibandingkan perlakuan kontrol, semakin tinggi dosis radiasi yang diberikan maka semakin panjang atau lamanya umur panen. 
Tabel 9. Umur Panen Pada Berbagai Dosis Radiasi

\begin{tabular}{|c|c|c|c|c|}
\hline Dosis radiasi (gray) & Umur panen (hari) & Galur *) & Jumlah galur & Rata-rata (hari) \\
\hline & 115 & T1-T30 & 30 & \multirow{3}{*}{119,9} \\
\hline \multirow{2}{*}{0 gray (Kontrol) } & 120 & T31 - T72 & 42 & \\
\hline & 125 & T73 - T100 & 28 & \\
\hline \multirow{5}{*}{100 gray } & 110 & $\mathrm{~T} 1-\mathrm{T} 7$ & 7 & \multirow{5}{*}{123,1} \\
\hline & 115 & T8 - T31 & 24 & \\
\hline & 120 & T32 - T98 & 67 & \\
\hline & 125 & T99 - T188 & 90 & \\
\hline & 130 & T189 - T232 & 44 & \\
\hline \multirow{5}{*}{200 gray } & 110 & T1- T9 & 9 & \multirow{5}{*}{120,5} \\
\hline & 115 & $\mathrm{~T} 10-\mathrm{T} 43$ & 34 & \\
\hline & 120 & T44 - T157 & 114 & \\
\hline & 125 & T158 - T207 & 50 & \\
\hline & 130 & T208 - T221 & 14 & \\
\hline \multirow{4}{*}{300 gray } & 120 & $\mathrm{~T} 1-\mathrm{T} 46$ & 46 & \multirow{4}{*}{128,2} \\
\hline & 125 & T47 - T112 & 66 & \\
\hline & 130 & $\mathrm{~T} 113-\mathrm{T} 141$ & 29 & \\
\hline & 135 & $\mathrm{~T} 142-\mathrm{T} 221$ & 80 & \\
\hline
\end{tabular}

$\left.{ }^{*}\right)$ : Galur berurutan. Contoh ; T1-T30 (Galur 1 sampai dengan Galur 30

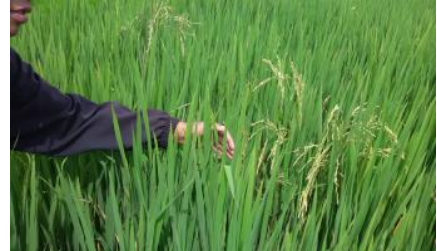

Gambar 1. Tanaman menandakan umur lebih pendek

Mutasi menyebabkan perubahan bahan genetik pada tingkat gen atau kromosom, berdampak pada

perubahan fenotipe atau sifat yang tampak (Djoar dan Nandariyah 2011). Hasil penelitian Rahayu (2009) menemukan terjadinya mutasi tanaman padi varietas IR64 yaitu pada perlakuan dosis 0,3 kGy menampilkan fenotipe akar yang lebih panjang dibandingkan perlakuan tanpa radiasi.

\section{KESIMPULAN DAN SARAN}

\section{Kesimpulan}

Kesimpulan yang dapat diambil dari penelitian mengenai keragaan padi Mentik wangi generasi M1 hasil iradiasi sinar gamma yaitu :

1. Diperoleh beberapa tanaman mutan yang memiliki karakter sifat lebih baik dari induknya, berada pada galur dengan perlakuan dosis radiasi tertentu yaitu : galur T16 dengan dosis radiasi 300 gray memiliki tinggi tanaman lebih pendek, galur T204 dengan dosis radiasi 200 gray memiliki panjang malai tertinggi, galur T133 dengan dosis radiasi 100 gray memiliki jumlah anakan total dan anakan produktif terbanyak, galur T133 dengan dosis radiasi 200 gray memiliki jumlah gabah isi terbanyak, galur T70 dengan dosis radiasi 100 gray memiliki persentase gabah isi tertinggi, galur $\mathrm{T}(1-7)$ dengan dosis radiasi 100 gray dan galur $\mathrm{T}(1-9)$ dengan dosis radiasi 200 gray memiliki umur panen lebih pendek.

2. Indikasi terjadinya mutasi diketahui dari keragaman genetik lebih luas pada nilai kisaran dan nilai rata-rata masing-masing perlakuan dosis yang lebih beragam. Keragaman genetik yang lebih luas untuk nilai kisaran terjadi pada peubah tinggi tanaman, jumlah anakan total, jumlah anakan produktif, panjang malai, jumlah gabah isi dan persentase gabah isi per rumpun, jumlah gabah hampa dan persentase gabah hampa per rumpun. Keragaman genetik yang lebih luas untuk nilai rata-rata terjadi pada peubah umur panen.

\section{Saran}

Perlu dilakukan penelitian lebih lanjut pada generasi selanjutnya (M2, M3, dst) untuk melihat sifat individu (morfologi dan fisiologi) khususnya pada tanaman yang berpotensi menjadi tanaman mutan tersebut sampai diperolehnya kestabilan genetik.

\section{DAFTAR PUSTAKA}

Abdullah, B., Prajitno, KS., Mudjisihono, R. 2006, Keragaan beberapa genotipe padi menuju perbaikan mutu beras, Subang (ID) : Balai besar penelitian tanaman padi sukamandi, URL:https://www.academia.edu/14819915/ 3._Isi_Prosiding_1_.pdf.

Bakhtiar, Purwoko, BS., Trikoesoemaningtyas, Dewi, IS. 2010, Analisis korelasi dan 
koefisien lintas antar beberapa sifat padi gogo pada media tanah masam, J Floratek, 5(2) : 86-93. URL http://jurnal.unsyiah.ac.id/floratek/article/vie w/389/373.

BB-BIOGEN, 2011, Pemanfaatan sinar radiasi dalam pemuliaan tanaman, $J$ Litbang Pertanian, 33(1), URL http://pustaka.litbang.pertanian.go.id/publik asi/wr331113.pdf.

Djoar, WD., Nandarriyah, 2011, Perbaikan sifat tanaman, Surakarta (ID) : UNS Press, ISBN : 978-979-498-676-9.

Haris, A., Abdullah, Bakhtiar, Subaedah, Aminah, Jusoff, K. 2013, Gamma ray radiation mutant rice on local aged dwarf, MiddleEast J Sci Res, 15(8) : 1160-1164, DOI: 10.5829/idosi.mejsr.2013.15.8.11541.

Herawati, R., Purwoko, BS., Dewi, SI. 2009, Keragaman genetik dan karakter agronomi galur haploid ganda padi gogo dengan sifat tipe baru hasil kultur antera, J Agron Ind, 37(2) : 87-94, URL http://repository.ipb.ac.id/handle/12345678 9/35829.

Islam, MZ., Khalequaman, M., Bashar, MK., Ivy, NA., Haque, MM., Mian, MAK. 2016, Variability assessment of aromatic and fine rie germplasm in bangladesh on quantitative traits, J Sci World, 2796720:14. URL http://dx.doi.org/10.1155/2016/2796720.

Kartikaningrum, S., Effenfie, K. 2005, Keragaman genetik plasma nutfah anggrek spathoglottis, J Hort, 15(4) : 260-269, URL http://balithi.litbang.pertanian.go.id.

Khikmah, M. 2014, Pengaruh dosis radiasi sinar gamma terhadap pertumbuhan bibit padi sawah, Skripsi, Program Studi Agronomi, Fakultas Pertanan, Universitas Sebelas Maret Surakarta.

Kristamtini, 2009, Keragaan beras hitam sebagai sumberdaya genetik lokal, prosiding risalah aplikasi paket teknologi "Mendukung Hari Pangan Sedunia". BPTP Yogyakarta. URL http://www.ejurnal.com/2015/05/keragaman-genetikdan-korelasi.html

Kumar, DP., Anurag, C., Sreedhar, M., Aparna, M., Babu, PV., Singhal, RK. 2013, Impact of gamma radiation stress on plant height and pollen fertilityin rice (oryza sativa L.), Asian J Exp Biol Sci, 4(1). URL http://www.ajebs.com/vol4(1)/20.pdf

Lehmann, A., Stahr, K. 2010, The potential of Soil functions and planner-oriented soil evaluation to achieve sustainable land use,
J Soils Sed, (10)5 : 1092-1102. DOI: 10.1007/s11368-010-0207-5.

Martono, B. 2010, Keragaman genetik dan heritabilitas karakter ubi bengkuang (pchyrhizus erosus L.), Balai penelitian tanaman rempah dan aneka tanaman industri, URL http://journal.unikal.ac.id/index.php/pertani an/article/view/15/2.pdf.

Medrano, M., Herrera, CM. 2008, Geographical structuring of genetic diversity across the whole distribution range of narcissus longispathus, Oxford J Ann Bot, 102 : 183194, DOI: 10.1093/aob/mcn086.

Mohamad, O., Nazir, M., Alias, I., Azlan, S., Rahim, A. 2006, Development of improved rice varieties through the use of induced mutations in Malaysia, Plant Mut Rep, 1(1) 27-34.

URL http://www.iaea.org/inis/collection/NCLColl ectionStore/_Public/38/047/38047363.pdf.

Rahayu, SY. 2009, Induksi mutasi dengan radiasi sinar gamma pada padi (oryza sativa L.) sensitif dan toleran aluminium, Tesis, Pascasarjana, Institut Pertanian Bogor.

Ramchander, S., Ushakumari, R., Arumugam, PM. 2014, Lethal dose fixation and sensitivity of rice varieties to gamma radiation, Indian J Agric Res, 49(1) : 24-31, DOI: 10.5958/0976-058X.2015.00003.7

Ritonga, AW., Wulansari, A. 2011, Pengaruh induksi mutasi iradiasi sinar gamma pada beberapa tanaman, URL http://www.aryaagh.files.wordpress.com/pe ngaruh-iradiasi.pdf.

Shaleh, MR. 2013, Aplikasi sinar gamma terhadap keragaan karakter tiga genotipe padi lokal generasi M1, Skripsi, Jurusan Budidaya Pertanian, Fakultas Pertanian, Universitas Hasannuddin.

Sobrizal, Ismachin, M. 2006, A significant contributing of mutation techniques to rice breeding in Indonesia, Plant Mut Rep, 1(1) : 18-21. URL http://wwwnaweb.iaea.org/nafa/pbg/public/pmr-0101.pdf.

Taher, HM., Hafiz, M., Sadat, S., Cirus, V., Reza, NM., Abbas, M. 2011, Sensitivity to gamma rays studies in two Iranian rice (Oryza sativa) genotypes, J Agricult Res, 6(23) : 5208-5211. DOI: 10.5897/AJAR11.384.

Vaughan, DA., Morishima, H., Kadowaki, K. 2003, Diversity in the Oryza genus, Current opinion in plant molecular biology, 6 : 139-146, DOI: 10.1016/S13695266(03)00009-8.

Agrosains 19(1): 6-14, 2017 
Wijaya, KA. 2006, Evaluasi keragaan fenotipe tanaman seledri daun (Apium graveolens L. Subsp. Secalinum Alef.) kultivar amigo hasil radiasi dengan sinar gamma cobalt60 (Co60), Skripsi, Bogor, Program Studi Hortikultura, Fakultas Pertanian, Institut Pertanian Bogor. 